\title{
LIFE CYCLE ASSESSMENT AND SIMULATION: ENABLERS OF SUSTAINABLE PRODUCT DESIGN
}

\author{
Gopinath Rathod ${ }^{1}$ Rohan $^{2}$, V.S. Puranik ${ }^{3}$ \\ ${ }^{1}$ Assistant Professor, Dept. of Mechanical Engg, Basaveshwar Engineering College Bagalkot, Karnataka, India \\ ${ }^{2}$ M.Tech, Dept. of Mechanical Engg, Basaveshwar Engineering College Bagalkot, Karnataka, India \\ ${ }^{3}$ Professor, Dept. of Industrial and Production Engg, Basaveshwar Engineering College Bagalkot, Karnataka, India
}

\begin{abstract}
Increasing global population contributes to the depletion of renewable and non-renewable resources. Designing an environmental friendly product is an important factor in this present developing environment. A product undergo various environmental impact starting from consumption of resources until its final disposal, to evaluate such environmental impact a methodology can be used known as Life Cycle Assessment (LCA). LCA has become a well known tool to provide information in respect to environmental performance for making decisions. One more method is concerned with LCA, Monte-Carlo Simulation. The capability of the product reusability can be obtained by the use of simulation and the results obtained from it. One of the case study for this perspective is carried for an organization which deals with the rotary switch.
\end{abstract}

Keywords: Green Manufacturing; Life cycle assessment; Monte Carlo Simulation; Environmental friendly product design.

\section{INTRODUCTION}

The increasing global population contributes to the depletion of renewable and non-renewable energy resources [9]. This situation stimulates the need for sustainability which is involves the reuse and remanufacture of the used products. Designing an environmentally friendlier product is an important factor in this present developing environment. Life cycle starting from consumption of natural resources through production and use phase of the product, until its final disposal at the end-of-life (EOL) should be evaluated for this purpose Life Cycle Assessment tool is used. LCA can be used as a tool for selection, design and optimization of processes. Thus, the economic and environmental evaluation through LCA is performed on the process alternatives to identify the best option that could further be subjected to process optimization. Apart from process design, LCA can be used as tool for process selection and decision making. It could be used for screening of technologies as a guiding tool for mapping the technology programs. LCA has became a well known tool to provide information in respect to environmental performances supporting decision making [3].

The resource saving plays a vital role towards sustainability [9]. The non-renewable resources are getting depleted from the planet at a faster rate. This is mainly because of increase in consumption. And to avoid this few methods such as reuse and reprocessing can be used after the end of product life cycle[10]. Remanufacturing comprises of the process as cleaning testing etc, to obtain a product to satisfy technical and safety specifications and its warranty as same as of new product. A method which can be used for this purpose is Monte Carlo simulation. One of the case study for this perspective is carried for an organization which deals with the rotary switch.

\section{LITERATURE REVIEW}

The LCA concept and sustainability principles have been incorporated by [1]. They had outlined LCA and resulted LCA can be used for the analysis.

Always in a development of a product comprises of various process till its delivery, such a management is called Environmentally Conscious Manufacturing and Product recovery which is stated by [6].

In a product life time it requires environmental requirements and this is presented by [8] and discussed environmental impact on product.

Many product can be reused after its life through proper testing, cleaning etc and this is stated by [2], for this purpose they have used Monte-Carlo simulation.

Based on LCA, the environmental performance in support to the decision making of both technical and valuation of uncertainities have been presented by [3], taking a key elemnt as "distinguish ability". 
A product from its initial state to the final discard, needs a proper planning and acquisition phases keeping in a mind for the reuse of the product and this can be made by the simulation framework which is presented by [12].

\section{CASE STUDY}

\subsection{About the Case Company}

For the case study to this paper a particular organization has been selected, which is a manufacturer of rotary switch and the organization known as ABC electronics limited situated in Tamil Nadu.

\subsection{Life Cycle Assessment (LCA)}

LCA can be used as a tool for selection, design and optimization of processes. Thus, the economic and environmental evaluation through LCA is performed on the process alternatives to identify the best option that could further be subjected to process optimization. Basically product development comprises of various stages, first of all taking information on requirements of customer, objective of the design, design and analysis, manufacturing and its usage. But for the development for the sustainability product environmental requirement also essential to introduce in the development phases. The issues concerned with the development cycle of sustainable product comprises of awareness of environmental impact to requirement of customers, for this objective and evaluation of product for its recycling and reuse [8] has been proposed a simplified LCA for recycle, reprocess and reuse after the end of life of product. To produce a new rotary switch, the organization manufactures the certain components, while the other components are purchased from suppliers. To produce a new rotary switch, the organization manufactures the knob/handle (C1), knob shaft (C2), front assembly (C3), mounting plate (C4), contact stages (C5) and front assembly (C6) in-house, while the other components, the contact spring (C7), latching spring (C8), terminal screw (C9), clamping bolt (C10) and nut (C11) are purchased from suppliers. The parts are then assembled to produce a switch. Producing a new switch with some re-manufacturing components requires a different production flow. It was assumed that the potentially re-usable parts could be obtained in the required high quality condition at the end of their first life, so that they could be used in the second lifetime. A cost model has been developed, integrating production and environmental costs as well as the technical status of an old part product for re-use. The model calculates the product gain (PG) as the difference between the product value (PVL) and the product life cycle cost (PLCC). PLCC includes product costs and environmental costs.

$$
\mathrm{PG}=\mathrm{PVL}-\mathrm{PLCC} \text {. }
$$

The technical status of a product is expressed by the term known as product effectiveness (PE). This is set to $100 \%$ for a new product and then decreased over time for a used part. PE indicates whether a part has re-use potential or not. As a sample, few rotary switch components and their EOL options are listed in Table-1. The proposed model has been applied for assessing the re-usability of each part and the switch as a whole. The results for part assessment are shown in Table-2. The following assumptions were made for the calculations. Based on the sensitivity analysis, the environmental cost is set as $10 \%$ of product cost and $1 \%$ of re-manufacturing cost. Therefore, these figures are used to calculate the environmental cost for the new and old product, respectively.

Table-1 Sample components and their re-manufacturing processes

\begin{tabular}{|l|l|l|l|}
\hline Component & Materials & $\begin{array}{l}\text { Market } \\
\text { Price } \\
\text { (INR) }\end{array}$ & $\begin{array}{l}\text { Required } \\
\text { re-manufacturing } \\
\text { processes }\end{array}$ \\
\hline C1 & ABS & 10.00 & Injection moulding \\
\hline C2 & Steel & 5.00 & Machining \\
\hline C3 & ABS & 18.00 & Injection moulding \\
\hline C4 & $\begin{array}{l}\text { Nylon- } \\
\text { GF }\end{array}$ & 8.00 & Injection moulding \\
\hline
\end{tabular}

Table-2: Assessment model for individual component

\begin{tabular}{|c|c|c|c|c|}
\hline Description & $\mathrm{C} 1$ & $\mathrm{C} 2$ & $\mathrm{C} 3$ & $\mathrm{C} 4$ \\
\hline \multicolumn{5}{|c|}{ Producing a new Component } \\
\hline Product cost & 8 & 4 & 15 & 6 \\
\hline Environmental cost & 0.8 & 0.4 & 0.15 & 0.6 \\
\hline $\begin{array}{l}\text { Product life cycle cost } \\
\text { (PLCC) }\end{array}$ & 8.8 & 4.4 & $\begin{array}{c}15.1 \\
5\end{array}$ & 6.6 \\
\hline Market price (MP) & 10 & 5 & 18 & 8 \\
\hline Product effectiveness (PE) & 1 & 0 & 1 & 1 \\
\hline PVL & 10 & 0 & 18 & 8 \\
\hline $\mathrm{PG}_{\mathrm{NC}}=\mathrm{PVL}-\mathrm{PLCC}$ & 1.2 & -4.4 & 2.85 & 1.4 \\
\hline \multicolumn{5}{|c|}{ Remanufacturing a old component } \\
\hline Procurement cost & 2.4 & 1.2 & 4.5 & 1.8 \\
\hline Re-manufacturing cost & 3.6 & 1.8 & 6.75 & 2.7 \\
\hline Environmental cost & 0.036 & $\begin{array}{c}0.0 \\
18\end{array}$ & $\begin{array}{c}0.06 \\
75\end{array}$ & 0.027 \\
\hline $\begin{array}{l}\text { Product life cycle cost } \\
\text { (PLCC) }\end{array}$ & 6.036 & $\begin{array}{l}3.0 \\
18\end{array}$ & $\begin{array}{c}11.3 \\
17\end{array}$ & 4.527 \\
\hline Market price (MP) & 10 & 5 & 18 & 8 \\
\hline Product effectiveness (PE) & 1 & 0 & 1 & 1 \\
\hline PVL & 10 & 0 & 18 & 8 \\
\hline $\mathrm{PG}_{\mathrm{OC}}=\mathrm{PVL}-\mathrm{PLCC}$ & 3.964 & $\begin{array}{c}- \\
3.0 \\
1\end{array}$ & $\begin{array}{c}6.68 \\
3\end{array}$ & 3.473 \\
\hline$\Delta \mathrm{PG}=\mathrm{PG}_{\mathrm{OC}}-\mathrm{PG}_{\mathrm{NC}}$ & 2.764 & $\begin{array}{c}.38 \\
2 \\
\end{array}$ & $\begin{array}{c}3.83 \\
3\end{array}$ & 2.073 \\
\hline
\end{tabular}


In the case product, all components have the positive values of $\triangle \mathrm{PG}$, which means they are feasible for re-use. If any component contain negative $\triangle \mathrm{PG}$, which indicates those components are not feasible for re-manufacturing.

\subsection{Simulation}

\subsubsection{Need for Simulation}

To support sustainability, a number of changes will need to be made in industry's approach to manufacturing simulation. The negative environmental effects of manufacturing on the environment have resulted in an increasing interest in sustainable manufacturing. Simulation has been used as an effective tool in the past to improve manufacturing operations. Risk and uncertainities are always a problem which we need to deal it. For the strategy of reuse, there are uncertainity.At a particular instance why the customer dispose goods, there is no idea of it for the industries. There will be many uncertainity like cost factor for the transport to dispose, crack, bent, rust may be other uncertainity during transportation or where they are fed in the dispose site. To handle such uncertainities simulation is an approach for this particular simulation, Monte-Carlo simulation can be used. Simulation is the classic approach to handle uncertainties. In this research, simulation is carried out using Monte Carlo simulation model. The model is developed based on the assessment model and the uncertainties are defined using relevant probability distributions from past practical experiences.

\subsubsection{Case Study}

For the research work rotary switches have been selected to demonstrate the applicability of the proposed method. The specification of the selected product is $10 \mathrm{Amp}, 230 \mathrm{VAC}$, Selector switch. This particular type of switch has been chosen because it has been released several years ago and has become one of the most popular products. Therefore sufficient data is available for the reliability assessment. The list of the main components and their quantity is shown in Table-3. The contribution of each component to the cost of good sold (CoGS) of a rotary switch is also shown in the last column of Table-3.

Table-3: Components of rotary switch

\begin{tabular}{|l|l|l|l|}
\hline $\begin{array}{l}\text { S1 } \\
\text {.No. }\end{array}$ & Component & Quantity & $\begin{array}{l}\text { Percentage of } \\
\text { Cost of goods } \\
\text { sold (CoGS) }\end{array}$ \\
\hline 1 & C1 & 1 & 8 \\
\hline 2 & C2 & 1 & 10 \\
\hline 3 & C3 & 1 & 15 \\
\hline 4 & C4 & 1 & 7 \\
\hline 5 & C5 & 3 & 20 \\
\hline 6 & C6 & 1 & 8 \\
\hline 7 & C7 & 6 & 3 \\
\hline
\end{tabular}

\begin{tabular}{|l|l|l|l|}
\hline 8 & C 8 & 2 & 2 \\
\hline 9 & C 9 & 12 & 6 \\
\hline 10 & C10 & 2 & 4 \\
\hline 11 & C11 & 2 & 1 \\
\hline
\end{tabular}

\subsubsection{Reliability Parameter}

The reliability parameters were adopted from Military Handbook on Reliability Prediction of Electronic equipment, Department of Defense, Washington, U.S (1995). Based on the input of the industrial partner and the available standard design, the reliability data for the 11 components of rotary switch in terms of their hazard rate $\lambda$ were available in section 14 of Military Handbook as shown in Table-4. It should be remarked that in most standards the exponential distribution represents well the product performance during the stable phase in its life cycle. If $\lambda$ is the hazard rate, the reliability formula for exponential distribution is shown in following equation; where ' $t$ ' represents the lifetime.

$$
R(t)=\exp [-\lambda t]
$$

Table -4: Reliability Parameters

\begin{tabular}{|l|l|}
\hline Component & $\lambda$ per day \\
\hline C1 & $1.735 \times 10-5$ \\
\hline C2 & $6.24 \times 10-5$ \\
\hline C3 & $4.035 \times 10-5$ \\
\hline C4 & $1.81 \times 10-5$ \\
\hline C5 & $2.56 \times 10-5$ \\
\hline C6 & $5.55 \times 10-6$ \\
\hline C7 & $1.81 \times 10-4$ \\
\hline C8 & $4.035 \times 10-4$ \\
\hline C9 10 & $2.10 \times 10-4$ \\
\hline C11 & $1.036 \times 10-4$ \\
\hline & $7.21 \times 10-5$ \\
\hline
\end{tabular}

\subsubsection{Model Implementation}

In order to run the simulation and calculate the parameters, some assumptions have been made. They are as follows:

- The life span of a rotary switch is 3 to 6 years, which equals to 1095 to 2190 days.

- Products have been taken back through a pooling system, meaning that the customers drop the used products at an assigned collection center. Then the used products are transported to the disassembly center.

- Mode of transportation for transporting used products to disassembly center is by road

- The normal capacity of the transportation vehicle is 3 tons which carries 5000 switches

- Average weight of a rotary switch is 60 grams 
- The distance between collection center and manufacturing site varies from 25 to $100 \mathrm{~km}$ with the most likely distance being around $50 \mathrm{Km}$.

- Within the normal carrying capacity, the diesel consumption remains constant which is 1 liter per 8 $\mathrm{Km}(0.125 \mathrm{l} / \mathrm{km})$. If the load is more than the normal capacity, the diesel consumption will gradually increase by 0.005 liter per $\mathrm{km}$ per additional $\mathrm{kg}$ of weight.

- The price of 1 liter diesel is INR 35/-

- Labor cost per hour INR 45/-

- Probability distributions used as inputs to the simulation are shown in Table-5.

Table-5: Input for Simulation

\begin{tabular}{|l|l|l|l|}
\hline Variable (Units) & $\begin{array}{l}\text { Distribution/For } \\
\text { mula }\end{array}$ & Mean & $\begin{array}{l}\text { Std. } \\
\text { Dev }\end{array}$ \\
\hline Usage life (days) & $\begin{array}{l}\text { Uniform(1095.0, } \\
2190.0)\end{array}$ & 1643 & 773 \\
\hline Distance (Km) & $\begin{array}{l}\text { Triang (25, 50, } \\
100)\end{array}$ & 58.15 & 15.62 \\
\hline $\begin{array}{l}\text { Disassembly time } \\
\text { (Hr) }\end{array}$ & $\begin{array}{l}\text { Normal(0.5, } \\
0.25)\end{array}$ & 0.51 & 0.23 \\
\hline $\begin{array}{l}\text { Cleaning and sorting } \\
\text { time (Hr) }\end{array}$ & $\begin{array}{l}\text { Normal(0.5, } \\
0.1667)\end{array}$ & 0.5 & 0.16 \\
\hline $\begin{array}{l}\text { Testing and } \\
\text { inspection time (Hr) }\end{array}$ & $\begin{array}{l}\text { Normal(0.1667, } \\
0.01667)\end{array}$ & $\begin{array}{l}0.166 \\
8\end{array}$ & 0.0167 \\
\hline \multicolumn{2}{|l|}{} \\
\hline
\end{tabular}

\section{RESULTS AND DISCUSSIONS}

\subsection{Results from LCA}

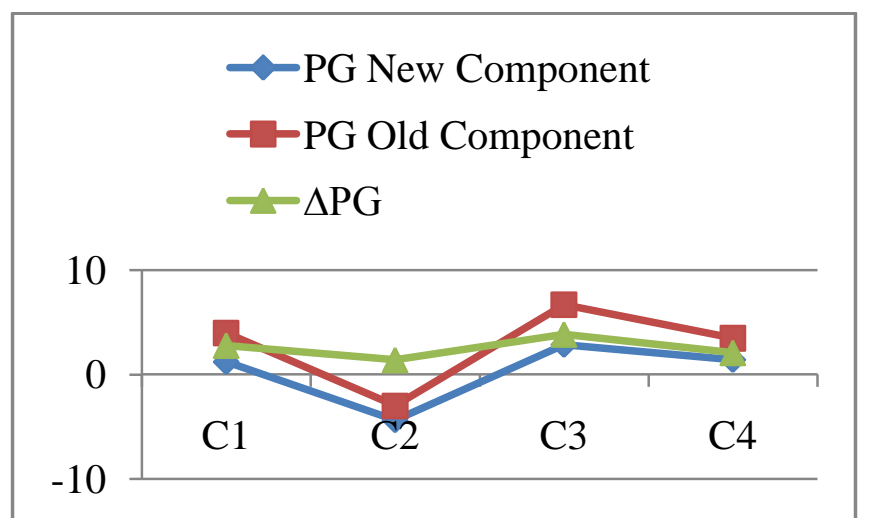

Chart-1: Comparison of PG, $\Delta \mathrm{PG}$ for old and new component

The comparison results for all parts of rotary switch are shown in Chart-1; Chart-1 shows that all components have the positive values of $\Delta \mathrm{PG}$, which means they are feasible for reuse. If any component contain negative $\Delta \mathrm{PG}$, which indicates those components are not feasible for re-manufacturing.

\subsection{Results from Simulation}

Chart-2 depicts the, plots the mean, minimum, and maximum values of PE for all components. The variation of technical feasibility is indicated in the chart-2. In summary, the results show that 6 components (54.5\% of total components) have technical potential of around 90 to100\% of reuse, while 2 components (18.2\% of total components) have the technical potential of around 80 to $90 \%$ of reuse, whereas 3 components (27.3\% of total components) have the technical potential of around 50 to $80 \%$ of reuse under simulation scenario. Table VI describes the brief simulation scenario of technical feasibility of a rotary switch.

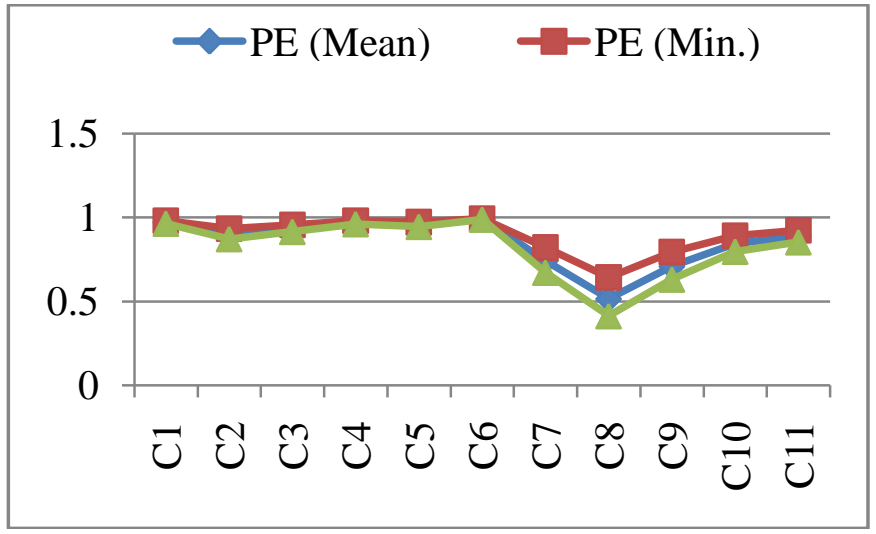

Chart-2: Product Effectiveness (PE) of rotary switch components

Table-6: Technical Feasibility

\begin{tabular}{|l|l|l|l|}
\hline $\begin{array}{l}\text { Compone } \\
\text { nt }\end{array}$ & $\begin{array}{l}\text { Technical } \\
\text { potential }\end{array}$ & Component & $\begin{array}{l}\text { Technical } \\
\text { potential }\end{array}$ \\
\hline C1 & 90 to $100 \%$ & C7 & 50 to $80 \%$ \\
\hline C2 & 90 to $100 \%$ & C8 & 50 to $80 \%$ \\
\hline C3 & 90 to $100 \%$ & C9 & 50 to $80 \%$ \\
\hline C4 & 90 to $100 \%$ & C10 & 80 to $90 \%$ \\
\hline C5 & 90 to $100 \%$ & C11 & 80 to $90 \%$ \\
\hline C6 & 90 to $100 \%$ & \multicolumn{3}{|l|}{} \\
\hline
\end{tabular}

\section{CONCLUSIONS}

The reduction of production cost and prevention of environmental problems for ensuring clean and green atmosphere is the focus of contemporary manufacturing organizations. Sustainable system tries to maximize resources efficiency for the production of sustained components [8]. Simulation has been used as an effective tool in the past to improve manufacturing operations. LCA and simulation model described in this paper provides a useful tool to decide upon the potential of reuse of a rotary switch components at the end of their life. The use of simulation significantly enhances the understanding of the impact of the contributing 
factors or parameters in the model. The implementation of the model in the case of an electronic device like rotary switch shows that there is a potential for parts reuse. Including the environmental cost in the model can increase the positive component of $\Delta \mathrm{PG}$. Therefore the model can be used in an economy driven environment, but still indicating the environmental friendliness of a component.

\section{REFERENCES}

[1]. Andersson K, Eide M H, Lundqvist U, Mattsson B The feasibility of including sustainability in LCA for product development Journal of Cleaner Production 1998; 6: 289-298 [2]. Anityasari M, Bao H, Kaebernick H. Evaluation of Product Reusability based on a technical and Economic Model: A Case Study of Televisions. IEEE International Symposium on Electronics \& the Environment, Electronics Recycling Summit, New Orleans, LA 2005; 199-204.

[3]. Basson L, Petrie J G. An integrated approach for the consideration of uncertainty in decision making supported by Life Cycle Assessment Environmental Modeling \& Software 2007; 22:167-176

[4]. Conteras A M, Rosa E, Prez M, Langenhove H V, Dewulf J. Comparative Life Cycle Assessment of four alternatives for using by-products of cane sugar production. Journal of Cleaner Production 2009; 17:772-779.

[5]. Gehin A, Zwolinski P, Brissaud D. A tool to implement sustainable end-of-life strategies in the product development phase Journal of Cleaner Production 2008; 16: 566-576.

[6]. Gungor A, Gupta S M. Issues in environmentally conscious manufacturing and product recovery a survey Computers and Industrial Engineering 1999; 36:811-853

[7]. Kaebernick H, Anityasari M., Kara S. A technical and economic model for End-of-Life (EOL) options of industrial products. International Journal of Environmental and Sustainable Development 2002;1(2):171-183

[8]. Kaebernick H, Kara S, Sun M. Sustainable product development and manufacturing by considering environmental requirements. Robotics and Computer Integrated Manufacturing 2003; 19:461-468.

[9]. Seliger G. Sustainability in Manufacturing - Recovery of Resources in Product and Material Cycles Springer - Berlin 2006.

[10]. Seliger G. Sustainability in Manufacturing - Recovery of Resources in Product and Material Cycles Springer - Verlag 2007.

[11]. Severengiz S, Widera H, Seliger G, Saavedra Y M B, Ometto A R. Scenarios for the Remanufacturing of Machine Tools and Assembly Equipment. Proc. Of the 7th Global Conference on Sustainable Manufacturing and Life Cycle Engineering, Indian Institute of Technology, Madras, Chennai, India 2009; 213-218.

[12]. Cople D G, Brick E S. A simulation framework for technical systems life cycle cost analysis. Simulation Modeling Practice and Theory 2010; 189-34 